\title{
A SCHEDULING SYSTEM FOR ENHANCING AND MONITORING WORK PERFORMANCE OF FIELD EMPLOYEES
}

\author{
Büşra ÖZDENiZCi KÖSE*, Aybüke ÇAKICl**, Vedat ÇOŞKUN** \\ Tolunay KAYMAKÇl***, illayda IŞLEK***, Mohammed ALSADI**
}

\begin{abstract}
Today, field sales and service businesses are continuously endeavoring to form their processes and operations more effective. Managing field employees and their tasks (or activities) are often difficult in most organizations. In field sales and service businesses, organizations mostly have problems with communicating work plans to employees since the workforce is spread over different areas having unique geospatial data. They need smart scheduling and planning information systems to make things planned and organized at the work environment and to automate sales and sales force management functions; and also to plan, track, and manage the allocation of labor resources. This study presents a Geographical Information System (GIS) based comprehensive scheduling system, called Scheduler+ for planning, organizing and monitoring the field employees and streamlining operations of field sales and service businesses. The proposed system aims to ensure dynamic and automatic scheduling customer point based tasks, to provide support to employees, to record the data to be obtained during the realization of tasks, and also to enable reporting and tracking of work performance. In this context, this paper presents the general design and analysis issues including the system context, modules, functionalities, some user interface designs and main development considerations.
\end{abstract}

Keywords: Scheduling, GIS, Task Management, Map, Calendar

Received:20.08.2021 ; Accepted :24.08.2021 - Research DOI.: 10.20854/bujse.985510

1Corresponding Author: Büşra ÖZDENIZCİ KÖSE Gebze Technical University, Koaceli/Turkey, busraozdenizci@gtu.edu.tr 2Beykent University, Istanbul/Turkey, 3Geovision Group, Istanbul/Turkey 


\title{
SAHA ÇALIŞANLARININ IŞ̧ PERFORMANSINI ARTIRMA VE IZLEMEYE YÖNELIK BIR PLANLAMA SISTEMI
}

\author{
Büşra ÖZDENIZCi KÖSE*, Aybüke ÇAKICI**, Vedat ÇOŞKUN** \\ Tolunay KAYMAKÇI***, İlayda işLEK ${ }^{* * *}$, Mohammed ALSADI**
}

ÖZ

Günümüzde saha satış ve hizmet organizasyonları, süreç ve operasyonlarını daha etkin hale getirmek için sürekli çaba sarf etmektedir. Saha çalışanlarını ve görevlerini yönetmek çoğu organizasyonda genellikle zorlu bir süreçtir. Saha satış ve hizmet işletmelerinde, iş gücü benzersiz coğrafi verilere sahip farklı alanlara yayıldığından, kuruluşlar çoğunlukla iş planlarını çalışanlara iletmede sorun yaşarlar. Çalışma ortamında işleri planlayıp organize etmek, satış yönetimi işlevlerini otomatikleştirmek ve ayrıca iş gücü kaynaklarının tahsisini planlamak, izlemek ve yönetmek için akıllı zamanlama ve planlama bilgi sistemlerine ihtiyaçları duyarlar. Bu çalışma, saha çalışanlarını planlamak, organize etmek ve izlemek ve saha satış ve hizmet organizasyonlarının operasyonlarını kolaylaştırmak için Scheduler+ adı verilen Coğrafi Bilgi Sistemi (CBS) tabanlı kapsamlı bir planlama sistemi sunmaktadır. Önerilen sistem, müşteri nokta bazlı görevlerin dinamik ve otomatik olarak planlanmasını, çalışanlara destek sağlamayı, görevlerin gerçekleştirilmesi sırasında elde edilecek verileri kaydetmeyi ve ayrıca iş performansının raporlanmasını ve izlenmesini sağlamayı amaçlamaktadır. Bu kapsamda, bu çalışma sistem bağlamı, sistem modülleri, işlevsellikler, bazı kullanıcı arayüzü tasarımları ve temel sistem geliştirme konuları dahil olmak üzere genel tasarım ve analiz konularını sunmaktadır.

Anahtar Kelimeler: Planlama, CBS, Görev Yönetimi, Harita, Takvim 


\section{INTRODUCTION}

Nowadays, businesses and professionals are persistently endeavoring to form their processes and operations more effective and robust. Organizations need smart information systems to make things planned and organized at the work environment. Especially for business like field sales and logistics, service; scheduling and planning information systems have a critical role to automate and streamline sales and sales force management functions; and also to plan, track, and manage the allocation of labor resources [1,2].

The term scheduling system or software have various definitions depending on the purpose of the business used. Davidson [3] describes scheduling systems simply as 'a method of using scheduling algorithms and rules to help multiple people manage appointments and meetings'. This definition mainly emphasizes the streamlining of the scheduling process of clients, patients, and meetings. Another definition for scheduling software is that it supports businesses by enabling them to manage and track their own and employees' time, create and maintain employee schedules, assign workers to shifts or jobs and track everything in real-time' [4]. In a broader term, a valuable definition -for field sales and logistics like businessescan be automation of the scheduling process of tasks, employees and other resources of businesses $[5,6]$.

Managing field employees (i.e., field workers, mobile workers) and their tasks (or activities) are often difficult in most organizations. In field sales and service businesses, organizations have problems with communicating work plans to employees $[5,6]$ since the workforce is spread over different areas having unique geospatial data. Geospatial data is also known as geodata or spatial data that has locational information connected to a dataset such as address, city or ZIP code $[7,8]$. An effective scheduling system using geospatial data can help field sales and service businesses centralize accurate information at a single database, monitor task performance of field employees, optimize resources and increase customer engagement in different locations. Real-time monitoring and planning tool can also increase transparency and accountability by automatically generating optimized schedules.

Currently, there are various kind of scheduling software within the industry depending on their business purpose and design. Some popular examples are Acuity Scheduling, Wrike, Synchroteam, Vectera and more [4, 5]. Businesses use these scheduling systems to manage both internal and external activity planning which include different features like shared calendar, allocation and resource management features. According to the analysis of Capterra [5], a vast majority of the systems allow users to automate appointment bookings by offering a real-time view of their own time available. Most employee scheduling software let employees view their schedules, realize tasks, shift tasks based on employee availability in real time. They notify managers about required staffing changes in case of unexpected events and provide available employees. Some existing solutions also support mobile functionality which allows managers to operate this process on the go as well. Even, some of them can automatically sync calendars according to time zones of users and can send reminders to users regarding their plans and schedules. However, comprehensive scheduling software solutions are not widely available as yet which uses both geospatial data of customers and field employees (i.e., mobile workers) of the business; and accordingly plans and schedules the tasks of field employees and other resources of the business.

The aim of this study is to introduce a comprehensive scheduling system for planning, organizing and monitoring the field employees and streamlining operations of particularly field sales and service businesses. The proposed system, Scheduler+ aims to ensure dynamic and automatic scheduling customer point based tasks (e.g., visits, collecting orders, distribution of orders) and also manual updating of them; to provide location, communication, information gathering and similar support to employees during the realization of these plans; to record the data to be obtained during the realization of tasks; and to enable the consolidation, evaluation and reporting of collected information at the end of the day.

The proposed system will be distinguished from competing applications in that it is based on a Geographical Information System (GIS); every task is affiliated with a spatial data. In this regard, the system first creates route plan for the field employees by evaluating the spatial data of customer points through a routing algorithm; and then schedules and organizes the route plan into unique tasks on map as well as on calendar. The locations of tasks and movements of the field employees will be displayed on the map on the smartphone, locationbased information and support will be provided to the employees; on the other side the managers will be able to track their own staff on the map on the web browser.

The proposed system design issues and system functionalities are presented in this study in detail. The paper is organized as follows: In Section II, the proposed system's business and design context are described. 
Afterwards, in Section III, system functionalities and design considerations are presented through system components. System development considerations are summarized in Section IV and finally the conclusions and further work are presented in Section V.

\section{II.SYSTEM CONTEXT}

The proposed system have two main components: Web Scheduler+ which will be used by Managers, and Mobile Scheduler+ which will be used by Field Employees. In this sense, the generic business flow of proposed system can be summarized as follows:

(1) The Web Scheduler+ allows to create optimized routes and task plans for field employees in general and pushes them to mobile workers as field employees.

(2) The Mobile Scheduler+ displays all the tasks either on map or calendar; field employee as the owner of smartphone realize her tasks on different customer points, and also enters all task feedback details on her Mobile Scheduler+ application. (3) Continuous, real-time feedback is provided to the Manager's Web Scheduler+ in order to track and monitor the work performance as well as to get reports about earned value and performance.

Different types of tasks using geospatial data are possible depending on the purpose of business. For example, field sales representative can visit customer points in order to receive data (e.g., order, product, customer) through such as dynamic survey forms or taking photos; or distribution teams can realize their distribution or dispatching operations as tasks on diverse customer points; repair service or utility (e.g., electricity, natural gas, water) service technicians can realize maintenance tasks on different customer points.

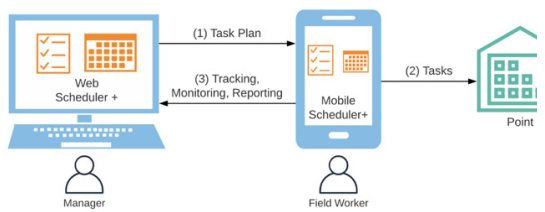

Fig. 1: Generic Business Flow

As mentioned and also illustrated in system context diagram of the proposed system in Figure 2, the Web Scheduler+ component is used by Managers as Admin; whereas Mobil Scheduler+ component is used by Field Employees. The other essential issues of the designed system context are as follows:

(1) The Web Scheduler+ is a group of Planner and Task
Manager modules:

(a) Planner module allows to plan and optimize a set of jobs (i.e., daily, weekly or monthly visits) for a set of field employees through a routing algorithm which runs based on spatial data along with set of rules. The planner module creates territories for customer points and produces an optimal route plan for each territory. (b) Task Manager module gets the planned data, creates tasks and assigns them field employees. These tasks can be displayed on a map or on a calendar; hybrid views are also possible.

(2) The Mobile Scheduler+ receives task information details from the Web Scheduler+ and directs field workers to realize the planned schedule. Field employee can view assigned task information, update task details and even create new task information on the calendar or map.

(3) The system will provide easy integration with other platforms:

(a) The system will use external map services (e.g., Google Map [9], Yandex [10], Here Map [11]), in order to obtain point location, traffic data and road data. This feature will support Planner module and allow field employees to perform their tasks in an time effective manner as well.

(b) Calendar systems such as iCalendar [12], Google Calendar [13], will collaboratively work with the proposed system through well-defined APIs (Application Programming Interface). The system will allow to automatically sync calendars according to users' time zones and can send regular alerts and reminders to users regarding their appointment schedules.

(c) Communication platforms will be integrated to the system as well in order to promote realtime communication, field employee performance improvement, issue handling and so on.

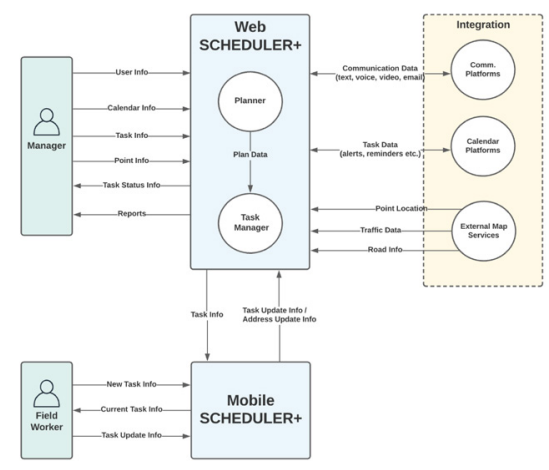

Fig. 2: Context Diagram 


\section{SYSTEM FUNCTIONALITIES}

The system modules and functionalities of Web Scheduler+ and Mobile Scheduler+ are explained hereunder in Table 1 and Table 2. In accordance with the functional requirements analysis, system user interface (UI) flows are started to be designed via Lucidchart software (https://lucid.app). This tool allows to model the interactions that users have with a product effectively and show how a user will navigate a software's interface. An UI example is also given in Figure 3.

Table 1:

System Modules and Functions of Web Scheduler+zz

\begin{tabular}{|c|c|}
\hline Syste & Fune \\
\hline $\begin{array}{l}\text { Login \& } \\
\text { User Settings }\end{array}$ & $\begin{array}{l}\text { - Admin can login to the program by using User ID \& } \\
\text { Password; or with face recognition; or with } \\
\text { fingerprint. } \\
\text { - Admin can change her password by entering her } \\
\text { current password; or by using the link in the SMS to } \\
\text { be sent to her phone; or by entering the code in the } \\
\text { SMS to be sent to her smartphone; or by clicking on } \\
\text { the link to be sent to her e-mail; or by entering the } \\
\text { code to be sent to her e-mail. } \\
\text { - The appearance and content of the web platform can } \\
\text { be customized. } \\
\text { - Admin can adjust settings related to the scheduler } \\
\text { language, tasks, activities and realization of point } \\
\text { visit. }\end{array}$ \\
\hline Point & $\begin{array}{l}\text { - New point(s) can be defined on the system. } \\
\text { Points can be added to the system via Excel file or } \\
\text { REST API. } \\
\text { - Points can be added manually by entering point } \\
\text { information. } \\
\text { - The points registered to the system can be displayed } \\
\text { on the map. } \\
\text { - The points registered to the system can be displayed } \\
\text { as a list. } \\
\text { - The selected point information can be updated. } \\
\text { - The selected point (if it is not attached to any } \\
\text { referential integrity rule) can be deleted. }\end{array}$ \\
\hline $\begin{array}{l}\text { Territory } \\
\text { Management }\end{array}$ & $\begin{array}{l}\text { All territories including their points can be } \\
\text { displayed on the map. } \\
\text { - New territory(s) can be created on the map. } \\
\text { Existing territory borders can be updated. } \\
\text { - Two or more territories can be merged. }\end{array}$ \\
\hline
\end{tabular}

\begin{tabular}{|c|c|}
\hline $\begin{array}{l}\text { Team } \\
\text { Management }\end{array}$ & $\begin{array}{l}\text { - New employee(s) can be defined on the system. } \\
\text { - Employees can be added to the system via Excel } \\
\text { file or REST API. } \\
\text { - A new employee can be added manually by } \\
\text { entering employee information. } \\
\text { - The live position of the employees who are in } \\
\text { working hours is displayed on the map. } \\
\text { - Employees registered to the system can be } \\
\text { displayed as a list. } \\
\text { - An employee defined on the system can be updated. } \\
\text { - An employee defined on the system can be deleted. }\end{array}$ \\
\hline $\begin{array}{l}\text { Task } \\
\text { Management }\end{array}$ & $\begin{array}{l}\text { Task types (such as sales, order, distribution, } \\
\text { survey) defined on the system can be displayed as a } \\
\text { list. } \\
\text { - Selected task type information can be displayed. } \\
\text { - A new task type can be added to the system } \\
\text { manually. } \\
\text { - A task type defined on the system can be removed } \\
\text { from the usage list. }\end{array}$ \\
\hline $\begin{array}{l}\text { Automatic } \\
\text { Planning and } \\
\text { Scheduling }\end{array}$ & $\begin{array}{l}\text { - Automatic planning (i.e., core function of the } \\
\text { system) can be performed through a routing } \\
\text { algorithm by using the data, constraints (e.g., daily } \\
\text { or 1-4 weeks), rules (e.g., shortest route, prevention } \\
\text { of zone intersections) and other target contents } \\
\text { entered by the admin. } \\
\text { - The system can create the automatic plan and } \\
\text { present it to the Admin. } \\
\text { - Admin can approve or reject the plan offered by the } \\
\text { system. } \\
\text { - Admin sends the approved plans as schedules to the } \\
\text { relevant employees. } \\
\text { - Plans and schedules of employees can be } \\
\text { downloaded as Excel or PDF. }\end{array}$ \\
\hline Map Operations & $\begin{array}{l}\text { Automatically planned and scheduled tasks can be } \\
\text { viewed and filtered with the parameters on map by } \\
\text { filtering parameters such as field employee, region, } \\
\text { segment, channel, frequency, or task type. } \\
\text { - The following operations can be done on map } \\
\text { manually: } \\
\text { - Task information can be displayed when } \\
\text { clicked. } \\
\text { Displayed task can be deleted. }\end{array}$ \\
\hline
\end{tabular}




\begin{tabular}{|c|c|}
\hline & $\begin{array}{l}\text { Displayed task can be updated. } \\
\text { A A new task can be defined for an employee by } \\
\text { clicking on a point. } \\
\text { Performed manual updates on map can be } \\
\text { saved and sent to employees after each change. } \\
\text { Route can be optimized again if necessary. } \\
\text { Admin is warned, if there are unfinished operations } \\
\text { when the browser screen is turned off. }\end{array}$ \\
\hline $\begin{array}{l}\text { Calendar } \\
\text { Operations }\end{array}$ & $\begin{array}{l}\text { - Automatically planned and scheduled tasks can be } \\
\text { viewed and filtered with the parameters on } \\
\text { calendar. } \\
\text { - The following operations can be done on calendar } \\
\text { manually: } \\
\text { - New task(s) can be defined to employees when } \\
\text { clicked on the empty slot. } \\
\text { Task information can be displayed when } \\
\text { clicked. } \\
\text { Displayed task can be duplicated for another } \\
\text { empty slot. } \\
\text { Displayed task can be updated; it can be } \\
\text { assigned to another person or time information can } \\
\text { be changed. } \\
\text { - Displayed task can be deleted. } \\
\text { Admin is warned, if there are unfinished operations } \\
\text { when the browser screen is turned off. } \\
\text { saved and sent to employees after each change. }\end{array}$ \\
\hline $\begin{array}{l}\text { Real-Time } \\
\text { Monitoring }\end{array}$ & $\begin{array}{l}\text { - The data to be displayed on the map can be filtered } \\
\text { with the parameters such as field employee, task in } \\
\text { a specific zone or in a particular category. } \\
\text { - The planned route and the actual route (real-time } \\
\text { view) can be displayed separately on map. } \\
\text { - When clicked on a point; customer point } \\
\text { information and details regarding visit can be } \\
\text { displayed. } \\
\text { - When clicked on a point; if the visit has been } \\
\text { completed, the result of visit information can be } \\
\text { displayed. } \\
\text { - When clicked on a point; communication with the } \\
\text { field employee can be started. } \\
\text { - When clicked on a point; if the visit has not started, } \\
\text { the task can be updated, or can be assigned to }\end{array}$ \\
\hline
\end{tabular}

\begin{tabular}{|c|c|}
\hline & $\begin{array}{l}\text { another field employee, or can be transferred to } \\
\text { another time. } \\
\text { When clicked on a point; if the visit has not started, } \\
\text { the task can be cancelled. }\end{array}$ \\
\hline $\begin{array}{l}\text { Task History } \\
\text { View on Map }\end{array}$ & $\begin{array}{l}\text { - The data to be displayed on the map can be filtered } \\
\text { with the parameters such as field employee, day, } \\
\text { zone, category. } \\
\text { - The planned route and the actual route can be } \\
\text { displayed separately on map. } \\
\text { - When clicked on a point; customer point } \\
\text { information, task status information and task } \\
\text { feedback details can be displayed. } \\
\text { When clicked on a point; communication with the } \\
\text { field employee or the regarding customer can be } \\
\text { started. } \\
\text { - Mission report for each point can be displayed. } \\
\text { Task history details can be downloaded as Excel or } \\
\text { PDF. }\end{array}$ \\
\hline $\begin{array}{l}\text { Task History } \\
\text { View on Calendar }\end{array}$ & $\begin{array}{l}\text { - The data to be displayed on the map can be filtered } \\
\text { with the parameters such as field employee, day, } \\
\text { zone, category. } \\
\text { - The planned route information and the actual route } \\
\text { information can be listed with their start and end } \\
\text { time details. } \\
\text { - When clicked on a point; customer point } \\
\text { information, task status information and task } \\
\text { feedback details can be displayed. } \\
\text { - When clicked on a point; communication with the } \\
\text { field employee or regarding customer can be } \\
\text { started. } \\
\text { - Mission report for each point can be displayed. } \\
\text { - Task history details can be downloaded as Excel or } \\
\text { PDF. }\end{array}$ \\
\hline Reporting & $\begin{array}{l}\text { Past transactions report can be downloaded. Some } \\
\text { examples of the useful reports that can be obtained } \\
\text { from the system are reports regarding mission plan, } \\
\text { update, deletion, initiation, completion; } \\
\text { performance and KPI analysis for a field employee; } \\
\text { all made communication details (who, with whom, } \\
\text { when, what was done etc.), and other similar event } \\
\text { logs. }\end{array}$ \\
\hline
\end{tabular}




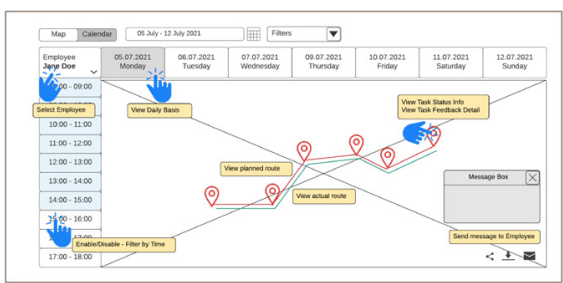

Fig. 3: A Sample User Interface Design of Real-Time Monitoring by Manager

Table 2: System Modules and Functional Requirements of Mobile Scheduler+

\begin{tabular}{|c|c|}
\hline & inctions \\
\hline User Settings & $\begin{array}{l}\text { - Authorized users can login to the program by using User ID \& } \\
\text { Password; or with face recognition; or with fingerprint. } \\
\text { - User (i.e., field employee) can change her password by entering her } \\
\text { current password; or by using the link in the SMS to be sent to her } \\
\text { phone; or by entering the code in the SMS to be sent to her smartphone; } \\
\text { or by clicking on the link to be sent to her e-mail; or by entering the } \\
\text { code to be sent to her e-mail. } \\
\text { - Employec profile information can be vicwed. } \\
\text { - Employee profile information can be updated. } \\
\text { - The appearance and content of the screens can be customized. } \\
\text { - The password used to login to the application can be updated. }\end{array}$ \\
\hline Task & $\begin{array}{l}\text { - User can view and filter their tasks in map format on the mobile } \\
\text { application. } \\
\text { - Completed and uncompleted tasks can be viewed with different colors } \\
\text { separately on map. } \\
\text { - The route of all assigned tasks for the current day can be displayed. } \\
\text { - When clicked on a point; customer point information, task status } \\
\text { information and task feedback details can be displayed. } \\
\text { - When clicked on a point, task details can be updated. The status } \\
\text { (result) of the assigned task can be entered. One task can be assigned } \\
\text { to another employee, and in that casc both customers and assigned } \\
\text { field employee are notified. The time can be changed, and accordingly } \\
\text { customer is informed. } \\
\text { - When clicked on a point; the task can be cancelled, and accordingly } \\
\text { the Admin is informed. } \\
\text { - Task can be realized by initiating the activity (e.g., visit) on map. Task } \\
\text { can be ended by clicking end activity on map. } \\
\text { - User can report problems (wheel exploded, customer failed, etc.) to } \\
\text { Admin. } \\
\text { - By clicking on an empty place on the map, a new task on a point can } \\
\text { be added. The customer can be informed about the upcoming ficld } \\
\text { employee visit. }\end{array}$ \\
\hline $\begin{array}{l}\text { Management on } \\
\text { Calendar }\end{array}$ & $\begin{array}{l}\text { - User can view and filter their tasks in calendar format on the mobile } \\
\text { application. } \\
\text { - Completed and uncompleted tasks can be viewed with different colors } \\
\text { separately on calendar. } \\
\text { - User can be informed about the changes in the calendar. }\end{array}$ \\
\hline
\end{tabular}
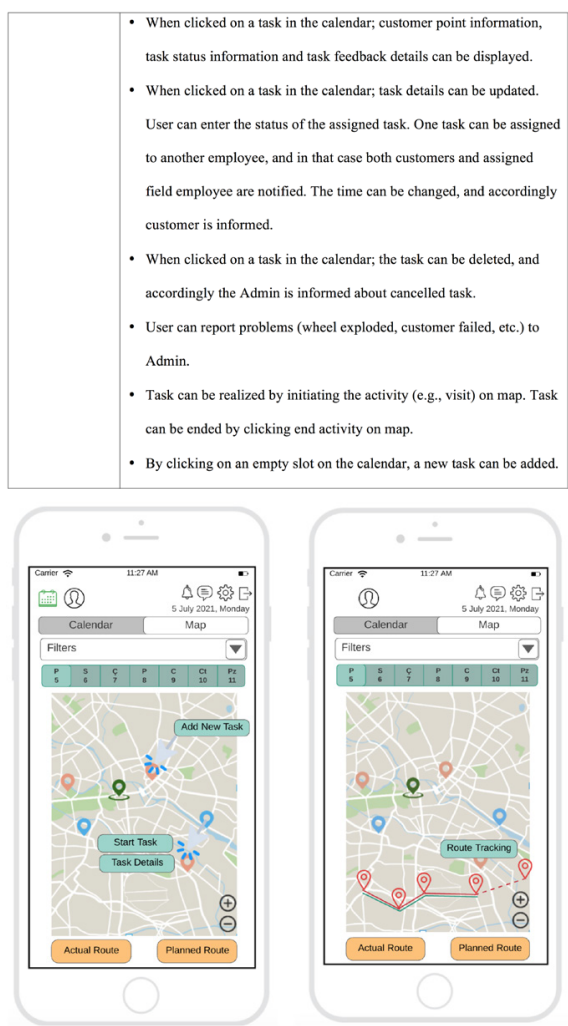

Fig. 4: A Sample User Interface Design of Task Management on Map by Field Employee

\section{IV.DEVELOPMENT CONSIDERATIONS}

For developing the system use cases of proposed system; the most appropriate and necessary tools are selected:

(1) For the web service of the system, it was preferred to develop a Java server software integrated with the high-performance and well-equipped Dropwizard Framework.

(2) PostgreSQL, which is used as the database infrastructure, is connected to this server software using the Hibernate ORM tool.

(3) IntelliJ IDEA integrated development environment tool is used for structuring and development of the backend server software.

(4) GeoServer, which is an open source server for sharing geospatial data, is used for receiving data from major spatial data sources that use open standards.

(5) React and React Native JavaScript libraries are used to design the frontend part (web and mobile) of the system, which enables fast and effective development. 


\section{CONCLUSIONS AND FURTHER WORK}

This paper introduces a comprehensive scheduling system for planning, organizing and monitoring the field employees and streamlining operations of particularly field sales and service businesses. By using the GIS capabilities, Scheduler+ will ensure automatic scheduling and management of customer point based tasks. The system will produce a route plan for a field employee by evaluating the spatial data of customer points through a routing algorithm; and then it will schedule and organize the route plan into unique tasks on map as well as on calendar of field employee. Location-based information and support will be provided to the field employees through mobile application; whereas the managers will be able to monitor and track their team's performance.

With this study, the system context, modules with functionalities, and development considerations are introduced in detail. Also, some examples regarding the user interface designs are demonstrated. The further work will focus on the details of Web and Mobile Scheduler+ development and implementation results of the described system modules and functionalities. 


\section{REFERENCES}

[1] Ivert, L. K., \& Jonsson, P. (2010), The potential benefits of advanced planning and scheduling systems in sales and operations planning. Industrial Management \& Data Systems.

[2] Kreipl, S. and Dickersbach, J.D. (2008), "Scheduling coordination problems in supply chain planning", Annuals of Operations Research, Vol. 161 No. 1, pp. 103-23.

[3] Davidson, E. (2021). What Is a Computerized vs. Manual Scheduling System? Chron. Online Access: https://smallbusiness.chron.com/computerized-vs-manual-scheduling-system-11956.html

[4] Software Advice (2021). Scheduling Software. Online Access: https://www.softwareadvice. com/scheduling/\#buyers-guide

[5] Capterra (2021). Scheduling Software. Online Access: https://www.capterra.com/schedulingsoftware/?feature $=\% 5 \mathrm{~B} 20111 \% 5 \mathrm{D} \&$ sortOrder $=$ sponsored

[6] Diffley, W. (2021). Award-Winning Employee Scheduling Solutions, AAP. Online Access: https://www.aaphcm.com/en-us/articlesfromaap/scheduling

[7] Burrough, P. A., McDonnell, R. A., McDonnell, R., \& Lloyd, C. D. (2015). Principles of geographical information systems. Oxford university press.

[8] OmniSci (2021). Geospatial - A complete introduction. Online Access: https://www.omnisci. com/learn/geospatial

[9] Google Maps, https://developers.google.com/maps

[10] Yandex Maps, https://yandex.com/dev/maps/

[11] HERE Maps, https://developer.here.com

[12] Google Calendar, https://support.google.com/calendar

[13] Apple, iCalendar, https://www.icloud.com/calendar 